\title{
Living and working conditions of the professionals of the a Mobile Emergency Service ${ }^{1}$
}

\author{
Camila Fernanda Lourençon Vegian²
}

Maria Inês Monteiro ${ }^{3}$

The assistance provided by the Mobile Emergency Service (SAMU) may result in changes in the health of the workers. This is a cross-sectional epidemiological study which aimed to evaluate the sociodemographic, health and lifestyle characteristics and the working conditions among professionals of the SAMU in Campinas, SP, Brazil. A questionnaire was used to collect sociodemographic, lifestyle, health and work data. The sample consisted of 197 workers nurses, physicians, nursing technicians, auxiliary nurses, drivers and administrative personnel. There was a prevalence of males $(61.4 \%)$, mean age 39.1 years $(S D=8.3)$; married $(63.5 \%)$, with children (76.7\%); of the category of drivers (30.5\%), monitored by physicians $(18.3 \%)$ and auxiliary nurses (16.8\%); 42.1\% had additional employment, 48\% performed overtime and $25.3 \%$ worked more than 70 hours per week. The majority practiced physical (56.5\%) and leisure (96.5\%) activities. New facets of the life of these workers were revealed and may contribute to programs aimed at health promotion.

Descriptors: Emergency Medical Services; Emergency Medical Technicians; Ambulances.

\footnotetext{
${ }^{1}$ Paper extracted from Master's Dissertation "Capacidade para o trabalho e condições de vida e trabalho entre profissionais de um Serviço de Atendimento Pré-Hospitalar Móvel de Urgência" presented to Departamento de Enfermagem, Faculdade de Ciências Médicas, Universidade Estadual de Campinas, SP, Brazil.

${ }^{2}$ RN, Hospital das Clínicas, Universidade Estadual de Campinas, SP, Brazil. Master's Student in Nursing, Universidade Estadual de Campinas, SP, Brazil. E-mail: vegian@fcm.unicamp.br.

${ }^{3}$ RN, Ph.D. in Nursing, Associate Professor, Departamento de Enfermagem, Faculdade de Ciências Médicas, Universidade Estadual de Campinas, SP, Brazil. E-mail: inesmon@fcm.unicamp.br.
}

Corresponding Author:

Maria Ines Monteiro

Universidade Estadual de Campinas. Faculdade de Ciências Médicas

Departamento de Enfermagem

Rua Tessália Vieira de Camargo, 126

Cidade Universitária Zeferino Vaz

CEP: $13083-887$, Campinas, SP, Brasil

E-mail: inesmon@fcm.unicamp.br 


\title{
Condições de vida e trabalho de profissionais de um Serviço de Atendimento Móvel de Urgência
}

A assistência prestada pelo serviço de atendimento móvel de urgência (Samu) pode resultar em alterações na saúde dos trabalhadores. Este é um estudo epidemiológico transversal e teve como objetivo avaliar os aspectos sociodemográficos, saúde, estilo de vida e condições de trabalho entre os profissionais do Samu, em Campinas, SP, Brasil. Foi utilizado questionário com dados sociodemográficos, estilo de vida, saúde e trabalho. A amostra foi composta por 197 trabalhadores - enfermeiros, médicos, técnicos e auxiliares de enfermagem, motoristas e pessoal administrativo. Houve prevalência do sexo masculino $(61,4 \%)$, idade média de 39,1 anos $(\mathrm{dp}=8,3)$, casados $(63,5 \%)$, com filhos $(76,7 \%)$, da categoria de motoristas $(30,5 \%)$, seguido pelos médicos $(18,3 \%)$ e auxiliares de enfermagem $(16,8 \%), 42,1 \%$ tinham outro emprego, $48 \%$ realizavam hora extra e $25,3 \%$ trabalhavam mais de 70 horas semanais. A maioria praticava atividade física $(56,5 \%)$ e de lazer $(96,5 \%)$. Novas facetas da vida desses trabalhadores foram reveladas, podendo contribuir para programas voltados à promoção da saúde.

Descritores: Serviços Médicos de Emergência; Auxiliares de Emergência; Ambulâncias.

\section{Condiciones de vida y trabajo de los profesionales en un Servicio de Atención Móvil de Urgencia}

\begin{abstract}
La asistencia prestada por el Servicio de Atención Móvil de Urgencia (SAMU) puede resultar en alteraciones en la salud de los trabajadores de ese servicio. Este estudio epidemiológico transversal tuvo como objetivo evaluar los aspectos sociodemográficos: salud, estilo de vida y condiciones de trabajo entre los profesionales del SAMU, en Campinas, SP, Brasil. Fue utilizado un cuestionario con datos: sociodemográficos, estilo de vida, salud y trabajo. La muestra fue compuesta por 197 trabajadores: enfermeros, médicos, técnicos y auxiliares de enfermería, choferes y personal administrativo. Hubo prevalencia del sexo masculino $(61,4 \%)$, edad promedio de 39,1 años $(D E=8,3)$; casados $(63,5 \%)$, con hijos $(76,7 \%)$; de la categoría de choferes $(30,5 \%)$, seguido por los médicos $(18,3 \%)$ y auxiliares de enfermería $(16,8 \%) ; 42,1 \%$ tenían otro empleo, $48 \%$ realizaban horas extras y $25,3 \%$ trabajaban más de 70 horas semanales. La mayoría practicaba actividades físicas $(56,5 \%)$ y de ocio $(96,5 \%)$. Nuevas facetas de la vida de estos trabajadores fueron reveladas pudiendo contribuir con programas dirigidos a la promoción de la salud.
\end{abstract}

Descriptores: Servicios Médicos de Urgência; Auxiliares de Urgência; Ambulancias.

\section{Introduction}

Prehospital Care - PHC is represented in Brazil by the Mobile Emergency Service (SAMU), based on regulation No. $2048 / G M$ of November 5, 2002(1). Its main aim is to organize care as a form of rapid response to emergency demands, whether in the domicile, in the work place, on public roads, or in other places where the patient might be in need ${ }^{(2)}$. For the professionals working in $\mathrm{PHC}$, performing in the face of the unexpected is routine because workers seldom know what kind of service will be required, or the characteristics of the place and the agents that might interfere in the care provided. Other aspects should be highlighted, such as the need to take rapid decisions, the need to be in adequate physical condition, the exposure to stressful conditions and the high levels of anxiety, among others(3).

In addition to training in Basic Life Support and Advanced Life Support, the professionals in general, must have the temperament for the work activity, must 
have the capacity for teamwork, and must possess initiative and quick thinking to take rapid decisions, as well as self-control and emotional balance(4). The feelings arising from the practice and formation of PHC nurses in Porto Alegre were the target of a qualitative study which revealed that the nurses felt secure, motivated and prepared to work and that they experienced feelings of compassion, grief, anger, pity, sorrow and anxiety, and also considered the recognition and the fact that they are able to restore lives motivating ${ }^{(5)}$.

In a scenario where the studies directed toward employees that work in PHC are scarce and where the service in the country has only been in existence for a few years, this study aimed to:

- Characterize the sociodemographic profile of the workers;

- Investigate the living and working conditions of these professionals.

\section{Methods}

This is an epidemiological, descriptive study, conducted in the SAMU of the city of Campinas, SP, Brazil. A total of 197 workers of the following professions participated in the study: physicians, nurses, pharmacists, nursing technicians and auxiliary nurses, ambulance drivers, telephonists and radio operators and those involved in the service administration and management. The inclusion criteria employed were: professionals active in the period of data collection, which occurred between March and June 2009; and, when approached by the researchers, agreeing to participate in the study. Workers who were on some sort of leave or license during the period of data collection were excluded. The procedure for collecting data was through the use of the Demographic Data, Lifestyle and Health and Work Aspects Questionnaire (QSETS) created by Monteiro in 1996 and updated in 2009(6).

The study was submitted to the Ethics Committee of the Faculty of Medical Sciences of the State University of Campinas - UNICAMP and gained approval. To participate in the study, the workers signed the Terms of Free Prior Informed Consent. Statistical studies were carried out using the SPSS (Statistical Package for the Social Sciences) program. For the analysis between the categorical variables the Chi-square test was used.

\section{Results}

The sociodemographic data are presented in Table 1 . The ages ranged between 20 and 60 years, with a mean of 39.1 years (SD \pm 8.3 ), with the mean age of their children being 15.1 years, where the minimum age was two months and the maximum 35 years. The mean time spent with the education of their children was 3.8 hours daily. Of 193 respondents, 104 (53.9\%) reported completing a course in their work area.

Table 1 - Distribution of absolute and relative frequencies of the SAMU professionals, according to sociodemographic variables. Campinas, $2010(n=197)$

\begin{tabular}{|c|c|c|c|}
\hline Variables & Categories & $n$ & $\%$ \\
\hline \multirow[t]{2}{*}{ Gender } & Male & 121 & 61.4 \\
\hline & Female & 76 & 38.6 \\
\hline \multirow[t]{4}{*}{ Age (years) } & $20-29$ & 19 & 9.6 \\
\hline & $30-39$ & 90 & 45.7 \\
\hline & $40-49$ & 65 & 33.0 \\
\hline & $50-60$ & 23 & 11.7 \\
\hline \multirow[t]{4}{*}{ City of residence } & Campinas & 159 & 80.7 \\
\hline & Metropolitan cities & 31 & 15.7 \\
\hline & Non-metropolitan cities & 06 & 3.1 \\
\hline & Not given & 01 & 0.5 \\
\hline \multirow[t]{3}{*}{ Marital status } & Married & 125 & 63.4 \\
\hline & Single & 38 & 19.3 \\
\hline & Widowed, separated & 34 & 17.3 \\
\hline \multirow[t]{2}{*}{ Children } & Yes & 151 & 76.7 \\
\hline & No & 46 & 23.3 \\
\hline \multirow[t]{6}{*}{ Schooling } & Complete elementary education & 11 & 5.6 \\
\hline & Incomplete high school education & 04 & 2.0 \\
\hline & Complete high school education & 79 & 40.1 \\
\hline & Incomplete higher education & 25 & 12.7 \\
\hline & Complete higher education & 40 & 20.3 \\
\hline & Complete Post-graduation & 38 & 19.3 \\
\hline Total & & 197 & 100 \\
\hline
\end{tabular}

Regarding traveling to work, the most widely used means of transport was the car $(62.1 \%)$, followed by the bus $(18.5 \%)$, with the mean travel time being 47.8 minutes $(S D \pm 38)$. The predominant type of housing was brick built dwellings (91.8\%). Regarding religion $79.3 \%$ reported having some belief, with the Catholic religion being dominant (59.6\%). The data relating to the work are presented in Table 2, which shows the 11 professional categories that were approached. There were 11 employees on restricted duty $(5.8 \%)$, i.e. performing other work functions due to medical restrictions. The predominant employment contract was the bond with the city council through public concours (59.4\%), under the statutory regime. There was a statistically significant difference between the variables 'type of contract' and 'age' ( $p$-value<0.0001/ Chi-square test). 
Table 2 - Distribution of absolute and relative frequencies of the SAMU professionals, according to work characteristics. Campinas, $2010(n=197)$

\begin{tabular}{llcc}
\hline \multicolumn{1}{c}{ Variables } & \multicolumn{1}{c}{ Categories } & $\boldsymbol{n}$ & $\%$ \\
\hline Professional category & Auxiliary nurse & 33 & 16.7 \\
& Nursing technician & 17 & 8.6 \\
& Registered Nurse & 16 & 8.1 \\
& Physician & 36 & 18.3 \\
& Driver & 60 & 30.5 \\
& Radio operator & 09 & 4.6 \\
& Telephonist (TARM) & 14 & 7.1 \\
& Administrator & 06 & 3.1 \\
& Porter & 03 & 1.5 \\
& Pharmacist & 01 & 0.5 \\
& Manager & 02 & 1.0 \\
Work shift & Day & 107 & 54.3 \\
& Night & 74 & 37.6 \\
& Day and Night & 15 & 7.6 \\
& Not given & 01 & 0.5 \\
& & 197 & 100 \\
\hline
\end{tabular}

In regards to having other employment, $42.1 \%$ said they had another employment contract. The majority of these, $38.3 \%$, besides working in the SAMU, worked elsewhere, this being, in $80.5 \%$ of the cases, another health service. Approximately half of the workers (48\%) reported working overtime, and $50.3 \%$ of the professionals reported a period of unemployment at some stage in their professional lives. Regarding the total hours worked per week, $40.5 \%$ worked up to 36 hours; $18.4 \%$ from 37 to 49 hours; $15.8 \%$ between 50 and 69 hours; and $25.3 \%$ more than 70 hours. There was a statistically significant difference between the variables: 'performance of overtime' and 'gender' ( $p$-value 0.0083); 'total hours worked per week' and 'gender' (p-value 0.0260); 'work schedule' and 'age' ( $p$-value 0.0050) (Chi-square test). The predominant salary range was up to $R \$ 829.00$ $(32.6 \%)$ and the value of the minimum wage at the time of data collection was $\mathrm{R} \$ 465.00$.

The values regarding time and work are presented in Table 3.

Table 3 - Distribution of the minimum, maximum, mean and standard deviation values of the SAMU professionals, according to the variables: age work was commenced, time working in the area of health, for the city council, and in the SAMU, and total hours worked per week. Campinas, $2010(n=197)$

\begin{tabular}{|c|c|c|c|c|}
\hline Variables & Minimum & Maximum & Mean & Standard deviation \\
\hline Age working was commenced (in years) & 7.0 & 30.0 & 16.7 & 4.9 \\
\hline Time working in the area of health (in years) & 0.3 & 35.0 & 12.2 & 7.2 \\
\hline Time working for the city council (in years) & 0.1 & 28.0 & 8.9 & 6.7 \\
\hline Time working in the SAMU (in years) & 0.0 & 22.0 & 6.9 & 5.2 \\
\hline Total hours worked per week & 30.0 & 132.0 & 52.9 & 20.2 \\
\hline
\end{tabular}

Work accidents had occurred in $10.7 \%$ of the sample and, in most cases, once (66.7\%). Among the types of occurrences, accidents involving cutting-piercing materials $(28.6 \%)$ predominated, followed by traffic accidents with the ambulances (23.8\%), for example, overturning. The use of personal protective equipment was reported by $78.1 \%$ of the workers. Procedure gloves were the most cited $(83.6 \%)$, followed by protective goggles $(51.4 \%)$, masks $(43.6 \%)$, and boots $(40.7 \%)$, among others.

When asked about "what is tiring in the work", the four most frequent situations were: interpersonal relationships $(27.7 \%)$, the population do not know how to make correct use of the service $(16.4 \%)$, the high work demand $(11.8 \%)$, and weather conditions, such as excessive heat $(10.8 \%)$. Referring to the fact of liking the work, the most frequent responses were: to be able to exercise a type of care specific to the SAMU (41.9\%), i.e. without routines, in shifts, and care to patients who are mostly caught in life threatening situations and require a rapid onsite response; the fact of being able to help people with their work (41.9\%), and relationships with colleagues $(31.8 \%)$.

The results related to the health of the workers are presented in Table 4.

Table 4 - Distribution of absolute and relative frequencies of the SAMU professionals, according to aspects of health and lifestyle. Campinas, $2010(n=197)$

\begin{tabular}{llcc}
\hline \multicolumn{1}{c}{ Variables } & Responses & $\boldsymbol{n}$ & $\%$ \\
\hline Smoker & Yes & 43 & 21.8 \\
& No & 154 & 78.2 \\
Alcoholic beverage use & Yes & 94 & 47.7 \\
& No & 101 & 51.3 \\
& Not given & 02 & 1.0 \\
& & & (continue...)
\end{tabular}


Table 4 - (continuation)

\begin{tabular}{llcc}
\hline \multicolumn{1}{c}{ Variables } & Responses & $\boldsymbol{n}$ & $\%$ \\
\hline Physical Activity & Yes & 109 & 55.3 \\
& No & 84 & 42.7 \\
& Not given & 04 & 2.0 \\
Pain in the last 6 months & Yes & 112 & 56.9 \\
& No & 83 & 42.1 \\
Pain in the last week & Not given & 02 & 1.0 \\
& Yes & 88 & 44.7 \\
& No & 107 & 54.3 \\
Total & Not given & 02 & 1.0 \\
\hline
\end{tabular}

The body site mentioned as the most frequent for the occurrence of pain was the cervical spine: $65.7 \%$ in the preceding six months and $45.1 \%$ in the preceding week. The use of medication was referred to by $30.6 \%$, with antihypertensives being the most used (37.5\%). Some interviewees $(17.9 \%)$ reported having problems with sleep, with the main cause related to the night shift schedule $(24.1 \%)$. The majority reported having plans for the future $(94.4 \%)$ and responded affirmatively regarding the performance of leisure activities (96.5\%), with watching television the most frequent $(82.7 \%)$. Among the subjects who participated in the study, $57.5 \%$ were satisfied with the work, and $59.4 \%$ were satisfied with life.

\section{Discussion}

The data analysis showed the predominance of males among the subjects studied, which may be associated with the absence of females in the most frequent professional category, the drivers (30.5\%). Despite the increasing female participation in the labor market, this is still well below male participation ${ }^{(7)}$. In the present study males were predominant, a fact that can be justified by the demands for strength and physical fitness in the work of the SAMU(2). The predominance of complete high school education is justified by the sum of the drivers and of the nursing class, which together represented almost $64 \%$ of participants. To perform the function of nursing technician, a complete high school education is required, and as a prerequisite for being a driver, Regulation $814^{(8)}$ requires complete primary education. Auxiliary nurses must also have at least complete elementary education, in addition to professional training.

It was evident that the majority of the professionals had employment contracts that were made through public concours $(59.4 \%)$, in which the selection of candidates with better education and performance may have occurred. The mean age of 39.1 years demonstrates a profile of individuals of productive age, with the majority married and with children. The association between 'age' and 'type of contract' revealed no difference between the age groups and the type of contract. The perception was that older workers had bonds with the city council through the public concours and the younger ones, were temporarily employed. Almost half of the workers $(42.1 \%)$ had other employment contracts and the majority of them were male $(65.1 \%)$. There was a predominance of physicians who had more than one job. A study performed with doctors in Salvador highlighted the work overload, especially during extra duty shifts, which is worrying due to the consideration that the medical activity is based on the physician and patient interaction, study and scientific-technical training and that, to some extent, this can be compromised by the lack of time ${ }^{(9)}$. Regarding the drivers, the fact that they also work in shifts may allow the accumulation of jobs.

Also noteworthy is the total hours worked per week, over 70, with a maximum of 132 hours per week reported. In these situations, it was identified that, among all the professional categories, the physicians worked more hours per week (44.7\%). The fact that almost the majority of the individuals worked overtime may be associated with two reasons: the SAMU, due to its characteristic of readiness, promotes the probability of extrapolating the finishing time, i.e. in the case of care near the end time of the workday, by postponing the employee returning to the central base; and also, the work in events (such as concerts, races, etc.), in which the presence of the SAMU is requested, which allows the employee to perform overtime on their day of rest. It is important to note the significant statistical difference between 'the performance of overtime' and 'gender', and the 'total hours worked per week' and 'gender'. In reflecting on gender and work, the literature indicates that one of the most marked differences concerning the working day, i.e. the working week for women is about five times shorter than that of men; it was not possible to conclude the reason, perhaps this being optional or an impediment imposed by the labor market or even factors beyond their control, possibly activities related to the care of the family and home ${ }^{(7)}$. In general, it was observed that older people worked at night in the environment of the SAMU. Coincidentally, there was a statistically significant difference between the variables 'work schedule' and 'age'.

Traffic accidents involving ambulances are highlighted due to the high percentage of occurrences 
among the work accidents (23.8\%). A North American study conducted with 1175 emergency technicians found a prevalence of $8.6 \%$ of traffic accidents involving ambulances, with the suggestion that age and sleep were associated with this occurrence ${ }^{(10)}$. The prevalence of the constant relationship with people being tiresome allows several perspectives. One is directed toward the workers who had actual direct contact with the users of the service. These constantly interacted with many different people throughout their working day, both directly and indirectly, with fluctuating durations of the interpersonal relationship. In addition, the interests imposed in these relationships are also variable. The people who worked in a closed environment had less exposure. However, for those that interacted indirectly, through the telephone, there was a loss of communication, which could result in situations of fatigue and exhaustion. This fact was highlighted in a study on the working situation of telephonists, in which the way they speak, what they say, what they do not say and how they conduct a dialogue, created an artificial situation. This would certainly have effects on the psychic lives of the subjects involved(11). The working conditions and health of the SAMU telephonists can be influenced when the risk of death at the other end of the line is considered, which can be mitigated when they feel that they are participating in the work process and useful to society.

Regarding lifestyle, the main cause of sleep problems was associated with the work schedule. Shift work and night work, the disruption of the circadian rhythm of sleep, can cause serious impairment of brain function ${ }^{(12)}$. The level of life satisfaction was slightly higher than work satisfaction. Work satisfaction is a complex, subjective phenomenon, which varies depending on the circumstances and the time when the same person is considered $^{(13)}$.

\section{Conclusion}

The majority of participants were male, aged between 30 and 39 years, residents of Campinas, had children, and had complete high school education. The use of the car as a means of transportation to work, housed in brick built dwellings and following the Catholic religion were predominant. Eleven types of professionals participated: auxiliary nurses, nursing technicians, registered nurses, physicians, drivers, medical regulation service technicians (telephonists), radio operators, managers, administrative workers, porters and pharmacists. The category with the highest percentage of participation in the study was the drivers, followed by the physicians and the auxiliary nurses. The majority of the participants had ties with the city council through public concours, were part of the day shift and worked up to 36 hours per week, with a significant number of professionals who accumulated more than 70 hours worked per week (25.3\%). Almost half of the participants had other employment and performed overtime. The mean length of working in the SAMU was 6.9 years $(S D \pm 5.2)$. The majority did not ingest alcoholic beverages, did not smoke, practiced physical and leisure activities, and had plans for the future.

In reference to the work in the SAMU, it is important to know the characteristics of the professionals working in $\mathrm{PHC}$ and their working conditions for the development of programs aimed at maintaining and promoting the mental and physical health of the workers. It is believed that these are necessary when considering the work in PHC. Another aspect to be highlighted is the long working hours of the physicians, which should be better evaluated and studied by the relevant agencies. Due to this being a recent service in the country, it is suggested that, for the structuring of the SAMU, measures aimed at ensuring the health of its professionals are clearly contemplated considering the future of this service, with regard to the quality of care provided to users, as well as the conservation of the quality of life and work of these professionals.

\section{References}

1. Portaria GM/ MS n. 2048 de 05 de novembro de 2002 (BR). Dispõe sobre o regulamento técnico dos sistemas estaduais de urgência e emergência. Diário da República Federativa do Brasil. Brasília: Imprensa Oficial; nov 2002.

2. Campos RM. Satisfação da equipe de enfermagem do Serviço de Atendimento Móvel às Urgências (SAMU) no ambiente de trabalho. Natal (RN): Universidade Federal do Rio Grande do Norte; 2005. 193 p.

3. Vargas D. Atendimento Pré-Hospitalar: a formação específica do enfermeiro na área e as dificuldades encontradas no início da carreira. Rev Paul Enferm. 2006;25(1):46-51.

4. Cristina JA. Vivências de uma equipe multiprofissional de atendimento avançado pré-hospitalar móvel ao adulto em situação de atendimento em parada cardiorrespiratória. Ribeirão Preto (SP): Universidade de São Paulo; 2006. 138 p. 
5. Romanzini EM, Bock LF. Conceptions and feelings of nurses working in emergency medical services about their professional practice and training. Rev. Latino-Am. Enfermagem. 2010;18(2):108-12. Inglês, Português, Espanhol.

6. Monteiro MI. Instrumento para coleta de dados. Campinas, Grupo de Estudos e Pesquisas em Saúde e Trabalho. Universidade Estadual de Campinas, 2009.

7. Ministério do Planejamento, Orçamento e Gestão. Inserção no mercado de trabalho: diferenças por sexo e conseqüências sobre o bem-estar. Rio de Janeiro (RJ); 2001. 32 p.

8. Portaria n. 814/GM de 01/06/01 (BR). Dispõe sobre a normatização dos serviços de atendimento pré-hospitalar móvel. Diário da República Federativa do Brasil. Brasília: Imprensa Oficial; 2002.

9. Nascimento CL Sobrinho, Carvalho FM, Bonfim TAS, Cirino CAS, Ferreira IS. Condições de trabalho e saúde de médicos em Salvador, Brasil. Rev Assoc Med Bras. 2006;52(2):97-102.

10. Studnek JR; Fernandez AR. Characteristics of emergency medical technicians involved in ambulance crashes. Prehosp Disaster Med. 2008;23(5):432-7.

11. Vilela LVO, Assunção AV. Os mecanismos de controle da atividade no setor de teleatendimento e as queixas de cansaço e esgotamento entre os trabalhadores. Cad Saúde Pública. 2004;20(4):1069-78.

12. Fischer FM, Moreno CRC, Rotenberg L. A saúde do trabalhador na sociedade 24 horas. São Paulo Perspec. 2003;17(1):34-46.

13. Martinez MC, Paraguay AIBB, Latorre MRDO. Relação entre satisfação com aspectos psicossociais e saúde dos trabalhadores. Rev Saúde Pública. 2004;38(1):55-61. 